\title{
Biology of Anar Butterfly: Deudorix (Virachola) isocrates Fabricius (Lepidoptera: Lycaenidae) in Mid Hill of Himachal Pradesh
}

\author{
Himani Kaushal ${ }^{1}$, Mahender Singh Thakur ${ }^{1}$, Joginder Singh ${ }^{2}$ and Ramesh Lal ${ }^{3^{*}}$ \\ ${ }^{1}$ Department of Biosciences, Himachal Pradesh University, Shimla-171005, India. \\ ${ }^{2}$ Horticultural Research Station, Dr Y S Parmar University of Horticulture and Forestry, \\ Seobagh Kullu (HP)-175138, India. \\ ${ }^{3}$ CSK HPKV, Krishi Vigyan Kendra Kullu at Bajaura (HP)-175125, India.
}

Authors' contributions

This work was carried out in collaboration among all authors. All authors read and approved the final manuscript.

Article Information

DOI: $10.9734 / A R R B / 2021 /$ v36i430362

Editor(s):

(1) Dr. Layla Omran Elmajdoub, Misurata University, Libya.

Reviewers:

(1) Nabil Sabet A. Mustafa, National research Centre, Egypt.

(2) R. Nalini, Tamil Nadu Agricultural University, India. Complete Peer review History: http://www.sdiarticle4.com/review-history/67627

Original Research Article

Received 15 February 2021

Accepted 20 April 2021

Published 24 April 2021

\begin{abstract}
Aim: The study on biology of fruit borer, Virachola isocrates Fabricius was carried out under laboratory conditions.

Place and Duration of study: Study on the biology of $V$. isocrates was carried out under laboratory conditions in the Horticultural Research Station, Dr Y S Parmar University of Horticulture and Forestry, Seobagh Kullu in 2019.

Methodology: In order to study life cycle, $V$. isocrates reared in the laboratory and measurements of different stages were regularly recorded with the help of ocular micrometer and stage micrometer.

Results: The average incubation period was recorded to be of $8.66 \pm 2.05$ days. The developmental period of first, second, third, fourth and fifth instar was $2.66 \pm 0.46,3.33 \pm 0.46,3.66 \pm 0.46,3.33 \pm$ 0.46 and $3.33 \pm 0.46$ days, respectively. The total larval period was found to be of $15.33 \pm 6.94$ days. Pupal duration was found to be $15.33 \pm 6.94$ days. Total developmental period was completed within $40 \pm 4.08$ days through five larval instars on pomegranate.
\end{abstract}


Conclusion: An up to date knowledge about the incidence pattern of major insect pests and their life cycle studies is a prerequisite for implementation of an effective and successful management tactics.

Keywords: Anar butterfly; biology; Virachola isocrate; total developmental period, pomegranate.

\section{INTRODUCTION}

Pomegranate (Punica granatum L.) is one of the important commercial fruit crop of the tropical and sub-tropical regions of the world. In India, pomegranate is grown on $2,34,000$ ha area with a production of $28,45,000 \mathrm{MT}$ [1]. Due to the high economic returns being obtained with pomegranate, the area under pomegranate cultivation in Himachal Pradesh has increased to 2,847 hectares with a production of 3,215 MT [2]. In India, pomegranate is attacked by more than 45 insects [3] of which Pomegranate butterfly Deudorix (Virachola) isocrates is one the most obnoxious pest and has been reported to cause 40-90 per cent damage to pomegranate fruits [4].

During last decades, pomegranate crop has witnessed a tremendous growth potential in mid hill zone Himachal. However, its cultivation is adversely affected by Pomegranate butterfly, $V$. isocrates. It is a key pest of regular occurrence, the caterpillars of which bore into developing fruit and feed on the seeds. The hole made by the larva invites secondary infection causing fruit to rot and drop. For management of pest, the basic requirement is to have a good knowledge on biology, important characteristics and feeding behavior of the pest. The present study was undertaken to investigate the biology of $V$. isocrates along with other parameters under laboratory conditions and it provides the baseline information on immature stages, food plants and habitat in a particular locality which will definitely help in efficient pest management strategies

\section{MATERIALS AND METHODS}

Study on the biology of $V$. isocrates was carried out under laboratory conditions in the Horticultural Research Station, Dr Y S Parmar University of Horticulture and Forestry, Seobagh Kullu 2019. The developing fruits having small entry holes were collected from the unsprayed pomegranate plants and were kept in glass cages. The fresh food material (pomegranate fruits) was provided timely to ensure a good emergence of adults. After adult emergence, the male and female butterflies in 1:1 ratio were transferred to glass jars covered with muslin cloth. Cotton swab soaked in sugar solution
$(10 \%)$ was provided as a source of food. In each jar, pomegranate twigs having developing fruits and flowers were provided as substrate for oviposition. The eggs laid by females were removed from substrate with the help of camel brush and transferred to Petri plates containing moist filter paper to maintain a regular regime of moisture. Ten such Petri plates were maintained each having a group of about ten eggs. The incubation period was recorded. After hatching, ten neonate first instar larvae were transferred individually to developing fruits of pomegranate and kept in separate small containers. The change in larval colour and other morphological features were considered as indicators for the change of instars. Up to second instar, immature fruits were provided as food, but for third, fourth and fifth instars, developed fruit were given as food and these were shifted to glass jars. The food material was replaced regularly till the larvae pupated. We recorded the duration of different larval instars along with some important larval characteristics. After pupation, the pupae were removed within 2-3 days when cuticle had hardened, and kept in separate glass jars till adult emergence. Measurements of different stages i.e. the egg, the larvae, the pupae and the adult were regularly recorded with the help of ocular micrometer and stage micrometer. The observations on incubation period, larval period, pupal period and total developmental period were also recorded.

\section{RESULTS AND DISCUSSION}

The results pertaining to different parameters of biology of $V$. isocratesis are presented in (Table 1). Studies showed that total developmental period was completed within $40 \pm 4.08$ days through five larval instars on pomegranate under laboratory condition. The experimental data revealed that the female laid eggs on flowers, fruits (base, middle, top and calyx cup) and on leaves singly. The freshly laid eggs were shiny white in colour and more or less round in shape. In life cycle studies of $V$. isocrates Fabricius results are in conformity with the description of some earlier investigations for example Bhut et al. [5] who studied the life cycle of $V$. isocrates and stated that the female laid eggs on flowers, 
fruits and leaves singly. The freshly laid eggs were shiny white in colour. The length and breadth of eggs, first, second, third, fourth, fifth instar larvae, pupa and adult were also measured. The larvae were found to pass through five instars on pomegranate fruits in the laboratory. The average length and breadth of eggs measured $0.47 \pm 0.014 \mathrm{~mm}$ and $0.50+$ $0.45 \mathrm{~mm}$, respectively. The incubation period varied from 6 to 10 days with an average of 8.66 \pm 2.05 days. These findings are well supported by Karuppuchamy et al. [6], Singh and Singh [7], Tiwari and Mishra [8], Kumar et al. [9], Bhut, et.al [5] who also noticed five instars of this pest. In laboratory, the newly hatched first and second instar larvae fed initially on seed. The bore hole made by third instar larva was bigger in size and posterior end of the abdomen was seen through the bore hole. The fourth instar fed voraciously on seeds and excreta was pushed out of the entry holes as dry pellets or wet faecal matter which stunk around the holes. This could create an offensive smell. The fifth instar larva created lot of mess and offensive smelling fluid oozed out from the entrance hole. Sometimes, the hole was plugged with the anal end of larva. The larvae were found to pass through five instars on pomegranate fruits in the laboratory. These findings are well supported by Thirumurugan [10], Karuppuchamy et al. [6], Singh and Singh [7] and Tiwari and Mishra [8] who noticed five instars of this pest in contrast to Kabre and Moholkar [11] who observed only four instars of $V$. isocrates on pomegranate. The freshly hatched larva was cylindrical and creamy white in colour except head and last abdominal segments being black. The body of larva was covered with scattered white hairs. The average length and breadth of first instar larva measured $1.55 \pm 0.02 \mathrm{~mm}$ and $0.95 \pm 0.017 \mathrm{~mm}$, respectively. The width of head capsule measured $0.20 \pm 0.017$. The duration of first instar larvae varied from 2 to 3 days with an average $2.66 \pm 0.46$ days (Table 1 ).

The colour of second instar larva varied from creamy white to greenish brown with scattered hairs. The average length of second instar larva measured $6.94 \pm 0.037 \mathrm{~mm}$, while the breadth measured $2.44 \pm 0.044 \mathrm{~mm}$. The width of head capsule measured $2.44 \pm 0.044 \mathrm{~mm}$ and duration of second instar larvae varied from 2 to 4 days with an average $3.33 \pm 0.46$ days.

Third instar larva was similar to preceding instar but dark in colour with larger yellowish and boat shaped spots on abdomen. The average length, width and head capsule width of third instar larva measured $12.23 \pm 0.62 \mathrm{~mm}, 3.77 \pm 0.044 \mathrm{~mm}$ and $0.52 \pm 0.014 \mathrm{~mm}$, respectively. The average duration of third instar larvae was $3.66 \pm 0.46$ days.

The yellowish boat shaped spots disappeared in the stout fourth instar larva. The colour changed greenish to light brown. The average length, width and head capsule width of fourth instar measured $16.9 \pm 0.4 \mathrm{~mm}, 4.46 \pm 0.26 \mathrm{~mm}$ and $0.80 \pm 0.02 \mathrm{~mm}$, respectively. While, average duration of fourth instar larvae $3.33 \pm 0.46$ days.

The full grown larva was dark brown with pale yellowish patches and short hairs on the body. Full grown larva suspended its feeding, became motionless. The average length, width and head capsule width of fifth instar larva measured was $22.3 \pm 0.58 \mathrm{~mm}, 5.77 \pm 0.017 \mathrm{~mm}$ and $1.15 \pm$ $0.017 \mathrm{~mm}$, respectively. The average duration of fifth instar larvae was $3.33 \pm 0.46$ days.

The total larval period varied from 26 to 34 days with an average $30.58 \pm 0.82$ days. The present findings are in conformity with Butani [12] noted total larval period ranged from 18 to 47 days. Karuppuchamy et al. [6] mentioned total larval period ranged from 19 to 25 days.

The larvae pupated inside the damaged fruit or in tunnel made by the larva. The pupa of $V$. isocrates was light brown in colour, obtect and adecticous in shape. The average length of pupa was $13.79 \pm 0.028 \mathrm{~mm}$, while breadth was $6.06 \pm$ $0.094 \mathrm{~mm}$. The average duration of pupal stage was $15.33 \pm 6.094$ days.

The total developmental period of $V$. isocrates occupied on an average $40.0 \pm 4.08$ days ranging from 30 to 42 days. Similar observations was reported by Karuppuchamy et. al. [6] and Shevale [13]. Whereas, Khan [14] observed total developmental period of 30 to 60 days with mean of $46.50 \pm 2.91$ days on guava and Kumar et. al. [9] recorded total developmental period of 52 to 75 days with mean of $63.92 \pm 2.87$ days on pomegranate.

Adult butterflies were dull brown (males) to dark brown (females). The fore wings of both sexes were covered with brownish scales as well as large in size and dark in colour as compared to hind wings which had long tail like structure on its anal margin. The thorax was fairly large and covered with brownish hairs. Male butterfly had three bluish spots in the anterior region of each 
Table 1. Duration of different life stage and Morphometric of $V$. isocrates on pomegranate under laboratory condition

\begin{tabular}{|c|c|c|c|}
\hline $\begin{array}{l}\text { Developmental } \\
\text { stages }\end{array}$ & $\begin{array}{l}\text { Mean duration } \\
\text { (Days) }\end{array}$ & Range & $\begin{array}{l}\text { Body Dimensions } \\
(\mathrm{mm})\end{array}$ \\
\hline Egg & $8.66 \pm 2.05$ & $6-10$ & $\begin{array}{l}\text { Length }=0.47 \pm 0.014 \\
\text { Width }=0.50 \pm 0.45\end{array}$ \\
\hline $\mathrm{I}^{\text {st }}$ instar & $2.66 \pm 0.46$ & $2-3$ & $\begin{array}{l}\text { Head Capsule Width }=0.20 \pm 0.017 \\
\text { Body Length }=1.55 \pm 0.02 \\
\text { Body Width }=0.95 \pm 0.017\end{array}$ \\
\hline II $^{\text {nd }}$ instar & $3.33 \pm 0.46$ & $2-4$ & $\begin{array}{l}\text { Head Capsule Width }=0.31 \pm .014 \\
\text { Body Length }=6.94 \pm 0.037 \\
\text { Body Width }=2.44 \pm 0.044\end{array}$ \\
\hline III instar & $3.66 \pm 0.46$ & $2-6$ & $\begin{array}{l}\text { Head Capsule Width }=0.52 \pm 0.014 \\
\text { Body Length }=12.23 \pm 0.62 \\
\text { Body Width }=3.77 \pm 0.044\end{array}$ \\
\hline $\mathrm{IV}^{\text {th }}$ instar & $3.33 \pm 0.46$ & $2-5$ & $\begin{array}{l}\text { Head Capsule Width }=0.80 \pm 0.02 \\
\text { Body Length }=16.9 \pm 0.4 \\
\text { Body Width }=4.46 \pm 0.26\end{array}$ \\
\hline $\mathrm{V}^{\text {th }}$ instar & $3.33 \pm 0.46$ & $2-8$ & $\begin{array}{l}\text { Head Capsule Width }=1.15 \pm 0.017 \\
\text { Body Length }=22.3 \pm 0.58 \\
\text { Body Width }=5.77 \pm 0.017\end{array}$ \\
\hline Total Larval period & $30.58 \pm 0.82$ & $26-34$ & - \\
\hline Pupa & $15.33 \pm 6.94$ & $8-19$ & $\begin{array}{l}\text { Length }=13.79 \pm 0.028 \\
\text { Width }=6.06 \pm 0.094\end{array}$ \\
\hline $\begin{array}{l}\text { Total developmental } \\
\text { period }\end{array}$ & $40 \pm 4.08$ & $30-42$ & - \\
\hline Adult (Female) & - & - & $\begin{array}{l}\text { Length }=24.56 \pm 0.86 \\
\text { Wing Span }=44.7 \pm 0.82\end{array}$ \\
\hline
\end{tabular}

hind wing. The female butterflies had an orange patch on the apical region of each forewing. The average length of female was $24.56 \pm 0.86 \mathrm{~mm}$, while breadth ranged from $44.7 \pm 0.82 \mathrm{~mm}$. Adult butterflies lay eggs on flowers and fruits. Eggs are exposed outside until hatching and after hatching, the first instar larvae remain outside for some time before puncturing the fruit. Therefore, efficient control can be achieved by properly timing the sprays when eggs or young larvae are still on the fruits. Hence, locationspecific studies on $V$. isocrates are necessary for implementing a good pest management strategies.

\section{CONCLUSION}

Pest affecting the crop is of order Lepidoptera. The high levels of incidence of this pest cause changes in plants and also affect crop production. In present study the caterpillar bored into young fruits, fed on internal contents i.e. pulp and seeds. Due to this, fruit rotting and dropping occurred, Vegetables and fruits are the important component of our daily diet and these provide source of proteins, vitamins and other elements which are essential. Pest problem is one of the major constraints for achieving higher production in the crops. Managing and controlling insect pests is one of the keys to successful farming. Therefore, an up to date knowledge about the incidence pattern of major insect pests and their life cycle studies is a prerequisite for implementation of an effective and successful management tactics. The growers need to quickly recognize insect problems and prevent it from getting out of control. Thus, the present data on life cycle stages of this pest provides the baseline information on immature stages, food plants and habitat in a particular locality which will definitely help in pest management strategies.

\section{ACKNOWLEDGEMENTS}

The authors are grateful to Department of Biosciences, Himachal Pradesh University, Shimla, Horticultural Research Station, Dr Y S Parmar University of Horticulture and Forestry, 
Seobagh Kullu and CSK HPKV, Krishi Vigyan Kendra Kullu at Bajaura, India.

\section{COMPETING INTERESTS}

Authors have declared that no competing interests exist.

\section{REFERENCES}

1. Anonymous. Horticulture Development in Himachal Pradesh-At a Glancel; 2018.

2. Anonymous. Horticulture Development in Himachal Pradesh-At a Glance; 2019.

3. Butani DK. Pests of pomegranate. In: Insects and fruits. Periodical Expert Book Agency, Delhi. 1979;228.

4. Atwal AS. Pests of tropical and sub tropical fruits. In: Agricultural Pests of India and South East Asia. Kalyani Publisher, New Delhi (India). 1986;205-247.

5. Bhut JB, Borad PK, Gadhiya HA. Bionomics and evaluation of different biocides against anar butterfly, Virachola isocrates (Fabricius) infesting pomegranate. International Journal of Plant Protection. 2013;6(2):338-43.

6. Karuppuchamy P, Balasubramanian G, Sundara Babu PC. The biology of pomegranate fruitborer Deudorix isocrates. Madras Agriultural Journal. 1998;85(56):256-259.

7. Singh SB, Singh HM. Biology of Deudorix isocrates on its new potential host-aonla
(Emblica officinalis). Indian Journal of Entomology. 2001;63(1):19-25.

8. Tiwari AK, Mishra P. Biology of Deudorix isocrates Fabr. on aonla, Emblica officinalis. Annals of Plant Protection Sciences. 2007;15(2):335-7.

9. Kumar KP, Jayanthi PK, Naik SO, Verghese A, Chakravarthy AK. Biology of anar butterfly, Deudorix isocrates (Fab.)(Lycaenidae: Lepidoptera) on pomegranate, Punica granatum L. International Journal of Pure Applied Bioscience. 2017;5(1):498-503.

10. Thirumurugan A. Studies on insect pests of pomegranate and their control. M. Sc. (Ag.) Thesis, Agricultural College and Research Institute (TNAU), Killikulam TN (India); 1992.

11. Kabre GB, Moholkar PR. Studies on lifehistory of pomegranate fruit borer, Virachola isocrates Fab. Journal of Insect Science (India). 1992;5(2):213-215.

12. Butani DK. Insect pests of fruit crops and their control: 21. Pomegranate. Pesticides. 1976;10(6):23-6.

13. Shevale BS. Studies on Life Fecundity Table of Pomegranate Butterfly, Deudorix isocrates Fabricius. Annals of Plant Protection Sciences. 2003;11(3):253-257.

14. Khan MM. Biology and management of fruit borer, Virachola isocrates (Fab.) Infesting guava. Bangladesh Journal of Agricultural Research. 2016;41(1):4151.

(c) 2021 Kaushal et al.; This is an Open Access article distributed under the terms of the Creative Commons Attribution License (http://creativecommons.org/licenses/by/4.0), which permits unrestricted use, distribution, and reproduction in any medium, provided the original work is properly cited.

Peer-review history:

The peer review history for this paper can be accessed here: http://www.sdiarticle4.com/review-history/67627 